\title{
WORK RELATIONSHIP TERMINATED EMPLOYEES LEGAL PROTECTION TO GET SEVERANCE PAYMENT FROM PT. KERTAS LECESS RELATED TO LAW OF BANKRUPTCY AND LAW OF LABOR
}

\author{
Susilawati Ussy RafaRayya ${ }^{1}$ \\ ${ }^{1}$ Fakultas Hukum dan Magister Kenotariatan, Universitas Islam Bandung, Email: \\ susilawati_af@yahoo.com
}

\begin{abstract}
This research titled is work relationship terminated employees legal protection to get severance payment from PT. Kertas Lecess related to law of bankruptcy and law of labor. The position of the worker or labor can be seen in two aspects, namely in terms of juridical and socio-economic aspects. From a socio-economic point of view, workers need legal protection from the state for the possibility of arbitrary action by entrepreneur. The form of protection provided by the government is by making regulations that bind workers and employeee, in this case there is Law Number 37 of 2004 concerning Bankruptcy and Delaying Obligations of Debt Payment Jo. Law Number 13 of 2003 concerning Labor Jo. MK Decision No. 67 / PUU-XI / 2013PT. The regulation is used as a basis for employees of PT. Kertas Lecess to sue the BUMN to be declared bankrupt and responsible for paying severance for its employees. PT. Kertas Lecess is a stateowned enterprise (BUMN), which went bankrupt in September 2019. There are around 1800 workers who must receive termination of employment. The value of severance payment for workers affected by layoffs is around Rp. 300 billion. Employees affected by layoffs protest because they have not received severance payment and even 1,900 employees who have not received their salary for 4 years. PT. Kertas Lecess was decided bankrupt by the Surabaya Commercial Court as a result of the cancellation of the peace proposal submitted by 15 of his employees on September 25, 2018. With the above considerations, the Panel of Judges of the Surabaya District Court, decided to grant the request for a cancellation of peace (Homologation) and stated that PT. Kertas Lecess is proven guilty of negligence for the non-payment of the salaries of PT. Kertas Lecess employees.
\end{abstract}

ARTICLE INFO

\section{Keywords:}

Bankruptcy; PT. Kertas

Lecess; Severance pay

Cite this paper:

RafaRayya, S. U. (2020).

Work Relationship

Terminated Employees

Legal Protection To Get

Severance Payment

From PT. Kertas Lecess

Related To Law of

Bankruptcy And Law of

Labor. Widya Yuridika:

Jurnal Hukum, 3(1).

\section{INTRODUCTION}

According to the Trade Finance Economics Encyclopedia, bankruptcy is a condition where someone who by a court is decided bankrupt and whose assets or inheritance has been earmarked to pay debts. Whereas according to the Bankruptcy Rules, it can be 
interpreted as a general confiscation of all the assets of a Bankrupt Debtor whose management and settlement is carried out by the Curator under the supervision of the Supervising Judge as regulated in the Rules.According to Igor Klioutchnikova et.al, " Financial chaos is often perceived as a mess that often causes prostration and reckless actions. As a result, it increases the helplessness that prevents correct decisions. " 1

Those conditions can lead to bankruptcy for the company. Bankruptcy is a threat that is very likely to occur for anyone who manages a business. This threat does not only apply to newly established companies, but also to companies that have existed for decades.

According to Raffles "Lecess is quite unique, because he is bankrupt not through a direct request but from the cancellation of homologation so that it is automatically insolvent. So that the next process is to procure assets, and the behavior is also the same as other private companies, because he is a company, and his assets become state assets that separated ".2

PT. Kertas Lecess is a state-owned enterprise (BUMN), which went bankrupt in September 2019. There are around 1800 workers who must receive termination of employment. The value of severance payment for workers affected by layoffs is around Rp. 300 billion. ${ }^{3}$ Employees affected by layoffs protest because they have not received severance payment and even 1,900 employees who have not received their salary for 4 years. However, it is not possible to pay salaries and severance payment considering that the assets of PT. Kertas Lecess in the form of $623 \mathrm{M} 2$ land and the building above it located in Kebayoran Baru, Jakarta can only be auctioned according to the auction limit value of 11,492 billion Rupiah. ${ }^{4}$

Therefore it is precisely Daphne Chen's opinion that: 5 "The wealth effect makes debtors reduce work effort after bankruptcy. Once individuals file for bankruptcy, they no longer need to work to service their debt ".

With no salary and severance payment to employees, it is as if PT. Kertas Lecess is waiting to be sued by its employees and then decided bankrupt so that it can pay workers' rights even though the amount does not match the salary contained in the work agreement.

Furthermore, no salary is paid for 2 (two) years, it can mean that PT. Kertas Lecess is experiencing financial problems. This is according to Ellen Toback's prediction which explains that : ${ }^{\text {" }}$ Research on bankruptcy prediction has largely focused on traditional data such as financial ratios, stock data or macroeconomic data ".Ollof Wadel also

\footnotetext{
${ }^{1}$ Igor Klioutchnikova, Mariia Sigovaa, Nikita Beizerova Chaos, Theory in Finance, 6th International Young Scientists Conference in HPC and Simulation, YSC 2017, 1-3 November 2017, Kotka, Finland, P.369

2 https://ekonomi.kompas.com/read/2018/11/06/054600026/pt-kerta-leces-pailit-kurator-bereskanaset

3 https://jatimnow.com/baca-14008-pabrik-kertas-leces-pailit-karyawan-demo-minta-pencairanpesangon

${ }^{4}$ https://nasional.kontan.co.id/news/ppa-berhasil-jual-aset-kertas-leces-dalam-pailit

${ }^{5}$ Daphne Chena,, JakeZhao, The impact of personal bankruptcy onlabor supply decisions, P.41

${ }^{6}$ Ellen Tobback, Tony Bellotti, Julie Moeyersoms, Marija Stankova, David Martens, 2017, Bankruptcy prediction for SMEs using relational data, Decision Support Systems, HIm.2 diunduh dari : http://10.1016/j.dss.2017.07.004
} 
explained that " which makes the bankruptcy setting excellent for studies of not only risk factors, but also economic". 7

Related to the facts above, the writer is interested in researching in the form of a paper entitled "WORK RELATIONSHIP TERMINATED EMPLOYEES LEGAL PROTECTION TO GET SEVERANCE PAYMENT FROM PT. KERTAS LECESS RELATED TO LAW OF BANKRUPTCY AND LAW OF LABOR “. The identification of problems in this paper are: 1) How the laws rule the employees position whose salaries and severance have not been paid by PT. Kertas Lecess which was decided by Bankruptcy in 2019 ?; 2) What is the employees legal protection to get salary and severance payment?

\section{METHOD}

The nature of this research is normative legal research with the library research type. Normative legal research is research that uses secondary and primary materials. Secondary data is sought more from the perspective of legal writing methods, law in books is implemented into the paradigm of doctrinal law research, which is a study that examines the inventory of positive law, legal principles, legal discovery In concreto, legal systematics and synchronization tarap. Research using Law in books, consists of studies by taking theories derived from books, jurmal. Whereas primary legal material is obtained from regulations (UUKPKPU, UUK, PP concerning Wages) 8 which will be analyzed through qualitative methods in the bankruptcy case faced by PT. Kertas Lecess.

Robert C. Bogdan and Sari Knoop Biklen (1992) 9 say that there are five characteristics of qualitative research, namely:

1. qualitative research has the natural setting as direct source of data and researcher is the key instrument,

2. qualitative research is descriptive. The data collected are in the form of worlds or picture rather than numbers,

3. qualitative researchers are concerned with process rather than simply with outcomes or products,

4. qualitative research tend to analyze their data inductively, and

5. meaning is of essential concern to qualitative approach.

\section{Sample Determination Techniques}

The sample in this research was based on certain characteristics, characteristics and objectives and focused on employees legal protection which were laid off to get the right in the form of severance payment from bankrupted PT. Kertas Lecess is related to the bankruptcy law and labor law. In this study the informant is an employee of PT. Kertas Lecess and Legal Consultant of the Employees. The research instrument is the researcher himself. As a research instrument, researchers conduct observations, in-depth interviews, document collection, photographs, assistance and so on.

\footnotetext{
${ }^{7}$ Olof Wadell, Anna Bengtson and Susanne Åberg, From dusk till dawn: Attracting suppliers for resource mobilization during bankruptcy, Journal of Purchasing and Supply Management, HIm.3, diunduh dari ,https://doi.org/10.1016/j.pursup.2019.03.001

${ }^{8}$ Ronny Hanitijo Soemitro, Metode Penelitian Hukum dan Jurimetri, Ghalia Indonesia, 1993, P. 12.

${ }^{9}$ Bogdan, R. C. \& Biklen, S. K., Qualitative research for education: an introduction to the theory and methods. Boston: Allyn and Bacon, Inc. 1982, P. 29-32
} 


\section{Data collection technique}

Moleong, explained that the data collection must go through several very important parts called research techniques. The sections cover 6 (six) types, namely (1) knowing the source and type of data, (2) humans as instruments (3) participating observations, (4) interviews, (5) field notes, and (6) use of documents. In this study the data collection methods used were observation, interviews, document collection (documentation), data collection with the help of audio visual equipment. Data collection techniques are carried out with interviews with the intention of constructing people, events, activities, organizations, feelings, motivations, demands, concerns and unanimity. ${ }^{10}$.

\section{Data Collection Tool}

The tool used to collect data in this research is through literature study, which is collecting data by conducting a study of reviewers of books, notes, and reports that have to do with the problem being solved. 11

In this study, various occurrence, information, answers in the form of words and actions of people observed or interviewed, are the main types of data.

The main data types are written sources. While the second data is recorded through written notes or through a recorder. This is as stated by Lofran in Moleong, 12 that called the main data types in qualitative research are "words and actions of written data sources, photographs and statistics.

\section{Data analysis}

In this study, data analysis was performed using descriptive techniques. The stages in the analysis are: data collection, data reduction, data presentation, drawing conclusions and verification / interpretation.

\section{RESULTS AND DISCUSSION}

\section{Law Protection Theory}

The position of the worker or laborer can be seen in two aspects, namely in terms of juridical and socio-economic aspects. From a socio-economic point of view, workers need legal protection from the state for the possibility of arbitrary action by entrepreneurs. The form of protection provided by the government is to make regulations that bind workers, provide guidance, and carry out industrial relations processes. Industrial relations is basically a process of fostering communication, consultation and deliberation which is supported by the ability and high commitment of all elements in the company.

Legally, based on Article 27 of the 1945 Constitution, the position of the worker is the same as that of the company owner, but socially and economically the position of the two is not the same, where the company owner's position is higher than that of the worker/laborer. High and low positions in this employment relationship result in a relationship, giving rise to the tendency of the company owner to act arbitrarily to the workers/laborers.

In theory, there is a legal principle that says that workers and company owner have an equal position. In terms of labor, it is called a work partner. But in practice, the position of the two was not parallel. Entrepreneur as owners of capital have a higher position than

\footnotetext{
${ }^{10}$ Moleong, L. J, Metodologi Penelitian Kualitatif. Remaja Rosdakarya, Bandung, 1998, P.112.

${ }^{11}$ M. Nazir, Metode Penelitian, Ghalia Indonesia, Jakarta, 2003, P. 27.

12 Moleong, L. J , Op.Cit, P.114
} 
workers. This is clearly seen in the creation of various company policies and regulations

Protection of workers/laborers is intended to guarantee the fulfillment of basic workers/laborers' rights and ensure equal opportunities and treatment without discrimination on any basis to realize the welfare of workers/laborers and their families while taking into account developments in the progress of the business world.

Legal protection according to Philip, is always related to power, there are two powers that are always a concern namely government power and economic power. In relation to government power, the issue of legal protection for the people (governed), against the government (governing). In relation to economic power, the problem of legal protection is protection for the weak (economy) against the elbow (economy), for example protection for workers against company owners. ${ }^{13}$

\section{Laws rule the employees position whose salaries and severance payment have not been paid.}

The policy regarding the provision of severance payment for employees laid off by the company is regulated in Law No. 13 of 2003 concerning Labor Article 156 Paragraph (1) which reads:

"In the occurance of employment termination (PHK), the employer is required to pay severance payment and/or work tenure awards and compensation payments that should be received."

On the other sides, the Court's Decision No. 67 / PUU-XI / 2013, September 11, 2014, the Constitutional Court which gave an interpretation of the phrase "payment was confirmed." The phrase referred to is contained in Article 95 paragraph (4) of the Labor Law. follows:

The Court's decision No. 67 / PUU-XI / 2013, September 11, 2014 are as

1. Article 95 Paragraph (4) of the Labor Law (State Gazette of the Republic of Indonesia Number 4179) is contrary to the 1945 Constitution of the Republic of Indonesia as long as it is not interpreted: "Payment of workers 'wages owed takes precedence over all types of creditors, including creditors' bills. separatists, bills of state rights, auction offices, and public bodies established by the government, while payments for workers/laborers' rights take precedence over all bills including bills of state rights, auction offices, and public bodies established by the Government, except bills from separatist creditors " ;

2. Article 95 paragraph (4) of Law Number 13 of 2003 concerning Labor (State Gazette of the Republic of Indonesia Number 4179) does not have binding legal force insofar as it is not interpreted: "payment of wages of workers/laborers who are in debt take precedence over all types of creditors including bills separatist creditors, bills of state rights, auction offices, and public bodies established by the government, while payment of workers' rights takes precedence over all bills including bills of state rights, auction offices, and

13 Philipus M Hadjon , "Perlindungan Hukum Dalam Negara Hukum Pancasila”, Armico, Bandung, 2003, Hlm 42. 
public bodies established by the Government, except bills from separatist creditors ";

Constitutional Court granted the petition by making two new norms. If the company is decided bankrupt, the Constitutional Court said: (a) Workers' wages take precedence over payments of all types of bills and other creditors, including from separatist creditors and state tax bills. (b) Other workers' rights are prepaid from all bills and other creditors, except if the debtor has a separatist creditor. The Court gives a different position on wages and other workers' rights. Wages are placed in a higher position than other rights.

When a company is decided bankrupt, the main problem for workers is severance payment. When the Constitutional Court said that the payment of workers 'wages took precedence over tax bills and other creditors, the Court gave the reason that the workers' wages that had not been paid by the debtor before the bankruptcy was decided were the basic rights of workers that could not be written off or reduced.

Conversely, if workers have other rights, such as severance payment, based on the Constitutional Court's ruling above, the curator can pay severance payment after paying the separatist creditor's bill. Regarding severance payments, the Court did not change the position of workers. MK positions permanent workers as preferred creditors. Whereas related to payment of wages, the Court positioned the worker as the main creditor of the other creditors.

Workers whose experience work termination because the company where they work is bankrupt, are entitled to pay their salary. The right to receive wages arises for one of the following reasons. First, when the bankruptcy verdict is made, the debtor's operations continue to operate. In such situations workers' wages are paid until the bankruptcy decision is established.

Second, when the debtor is decided bankrupt, the debtor is in arrears on the wages of the workers. Third, wages arising after the bankruptcy decision. Noting these three reasons, the Constitutional Court's decision No. 67 / PUU-XI/2013 is positioned to protect workers' wages as stated in the second reason.

Companies whose operations stop after being sentenced bankrupt, automatically stop paying workers' wages. As a result, during the process of bankruptcy proceedings, workers are not paid. Furthermore, in Article 39 of Law Number 37 of 2004 concerning Bankruptcy and PKPU it is explained:

1. Workers whose work for the Debtor can terminate the employment relationship, and conversely the Curator can terminate it by observing the time period according to the agreement or the provisions of the applicable legislation, with the understanding that the employment relationship can be terminated with the shortest notice of 45 (forty five) days before;

2. Since the date of the bankruptcy statement is pronounced, the wages owed before or after the verdict of the bankruptcy statement is pronounced are bankruptcy debt;

Based on the provisions of Article 39 paragraph (2), wages that have not been paid before and after bankruptcy are qualified as debt. Source of funds to pay wages debt comes from bankruptcy assets. If the debtor is in arrears in workers' wages before the 
bankruptcy is decided, the Constitutional Court's decision No. 67/PUU-XI/2013 gives a rule, the curator must pay all arrears of wages.

In accordance with the Constitutional Court's decision, payment of state bills and separatist creditors is no longer the primary when workers submit bill payment of wages. The Constitutional Court puts the payment of workers' wages above all types of bills. Wage positions beat state bills and separatist creditors. A separate problem is layoff compensation. The Court said that the severance pay payment was prioritized from other bills, but was avoided from the separatist creditor bills, this was experienced by workers who were laid off by PT. Kertas Lecess due to bankruptcy. Therefore, the curator can pay severance payment first, if the debtor does not commit himself to a separatist creditor.

When viewed in terms of the interests of the curator, the Constitutional Court's decision No. 67/PUU-XI/2013 makes it easy for curators to carry out their duties. Curators do not need to argue anymore with workers, separatist creditors or tax officials. In short, the Constitutional Court's ruling did not cause problems for curators and bankrupt debtors. Bankrupt debtors and curators who should be happy to welcome the Constitutional Court's decision. When the curator pays severance payment and workers' wages ahead of other creditors for the debtor that doesn't matter. Conversely, for separatist creditors, of course the Constitutional Court's decision could be judged unfavorable.

Based on these provisions, all employees of PT. Kertas Lecess that was work terminated got its salary and severance payment. However, because the value of the auction limit was set at $\mathrm{Rp} 11.492$ billion, while the value of severance payment for workers affected by layoffs was around Rp 300 billion. ${ }^{14}$ Thus it is not possible for the Curator to manage the results of the auction to pay salaries and severance in accordance with statutory regulations.

Supposedly, PT. Kertas Lecess, when the company is in good health, aside from thinking about the salaries of employees, can also think of the worst possibility if the company goes bankrupt by preparing severance payment. This was stated by Caggese, A., Cuñat, V., \& Metzger, D. (2018) ${ }^{15}$ that "Firms consider wages, current and expected productivity, as well as firing costs when firing a worker". Then Boeri, T., Garibaldi, P., \& Moen, E. R. (2018) said that "A key lesson from the Great Recession is that firms' leverage and access to finance are important for hiring and firing decisions. ${ }^{16}$

These conditions make workers surrender and accept what severance payments are not in accordance with the provisions. In addition, the salaries of employees before bankruptcy were not paid due to the limited value of the auction. Whereas to get a bankruptcy decision through litigation requires a long time, but still must be taken by workers to get their rights. According to Espinosa, R., Desrieux, C., \& Ferracci, M. (2018)

${ }^{14}$ https://jatimnow.com/baca-14008-pabrik-kertas-leces-pailit-karyawan-demo-minta-pencairanpesangon

${ }^{15}$ Caggese, A., Cuñat, V., \& Metzger, D. (2018). Firing the Wrong Workers: Financing Constraints and Labor Misallocation. Journal of Financial Economics. doi:10.1016/j.jfineco.2017.10.008

${ }^{16}$ Boeri, T., Garibaldi, P., \& Moen, E. R. (2018). Financial constraints in search equilibrium: Mortensen Pissarides meet Holmstrom and Tirole. Labour Economics, 50, 144-155. doi:10.1016/j.labeco.2017.06.003 
17 " ... for many workers and employers who had to travel further to proceed with conflict litigation".

In article 59 paragraph (1) of Law 37/2004, separatist creditors are indeed given up to 60 days after insolvency to execute dependents. While Lecess was decided insolvent on September 25, 2018.

Related to this, Edi has another interpretation. According to him, the 60-day period did not start during the auction, but when the creditor began to carry out the execution process. It was further said that "The 60 days were not on the auction, but when the rights had begun. For example, the registration to the KPKNL had been calculated, and the implementation was still within 60 days. Although the auction had already passed. Going into the bankruptcy Boedel, Edi hopes that the proceeds of the sale will still be given to the PPA as his security rights.

Regarding the distribution of the bankruptcy boedel assets, Rayi said that his party would await the determination of the supervisory judge. "If it is not in accordance with the PPA mortgage, it means that it violates the law," While in Leces's bankruptcy, PPA is known to hold separatist bills worth Rp 104.706 billion.

Remind PT. Kertas Lecess was declared bankrupt by the Surabaya Commercial Court from a request for cancellation of homologation submitted by 15 employees. The request was submitted because the employee considered Leces did not meet the homologation in the previous PKPU process. The Lecess employees hold Rp 2.51 billion in bills originating from unpaid salaries and severance payment.

In the world of business debt - receivables is a natural. A business that wants to grow and then look for debt, is not something bad, as long as the company can pay it back. Means the company is in a "Solbavel" state. Conversely the company is in an "Insobavel" state if the company is no longer able to pay its debts. And if the state of the company continues to decline until a "stop paying condition" then the judge can decide the bankruptcy of the company. ${ }^{18}$

\section{In Article 1 paragraph (1) article 1 paragraph (1) UUKPKPU states that:}

"Debtors who have 2 (two) or more creditors and do not pay at least one debt which is due and collectible, are declared bankrupt by a court decision, either at their own request, or at the request of one or more of their creditors".

The article is implemented by employees to file a bankruptcy lawsuit PT. Kertas Lecess remembers that employee salaries have not been paid for 2 (two) years.

"This bankruptcy decision is a slap for the government, especially the BUMN Ministry. Why has the problem of employee rights not paid for years," said Eko. ${ }^{19}$

\footnotetext{
${ }^{17}$ Espinosa, R., Desrieux, C., \& Ferracci, M. (2018). Labor market and access to justice. International Review of Law and Economics, 54, 1-16. doi:10.1016/j.irle.2017.09.008

${ }^{18}$ Soeprapti, Kepailitan Debitur ditinjaudari kaca mata hukum, Ekuitas Vol.2 No.1 Maret 1998 , HIm.1

${ }^{19}$ http://www.djkn.kemenkeu.go.id/berita media/baca/12885/Penyelesaian-Aset-Selangkah-Lagi.html
} 
Therefore it is precisely Daphne Chen's opinion that:20 "The wealth effect makes debtors reduce work effort after bankruptcy. Once individuals file for bankruptcy, they no longer need to work to service their debt".

With no salaries and severance payment paid to employees, this can actually mean that PT. Kertas Lecess is waiting to be sued by its employees. It's as if PT. Kertas Lecess is waiting for a court ruling to declare bankruptcy so that workers can pay their rights even though the amount does not match the salary contained in the work agreement. The decision not to make a layoff is therefore a risk of high production, and in fact the production decreases in balance with the welfare of employees who also declined. As revealed by Yang, G. (2018), "Pairing firing rigidity with high production risk, firms reduce employment and output, which generates welfare loss ".21 Therefore the lawsuit starts precisely from the employees of PT. Kertas Lecess, because through the voice of employees can affect the financial side of the company to then lead to severance pay through court decisions. Research by Lin, C., Schmid, T., \& Xuan, Y. (2014) said that "We analyze how direct employee voice affects financial leverage. Surprisingly little is known about the consequences of a direct employee voice for corporate decision making"22. Thus, the company, after being declared bankrupt, decided to follow the judges' decision, surrendered the company's assets to the curator and then auctioned off to pay severance payment. It was as if intentional considering that PT. Kertas Lecess does not seek to improve employee welfare to strengthen the company's reputation, increase shareholder involvement, avoid strikes that can harm the company, and increase employee productivity, higher levels of employee welfare are expected to reduce the risk of a collapse in share values, as analyzed by Ben-Nasr, H., and Ghouma, H. (2018). “... if strong commitment to employee well-being genuinely aims at strengthening the firm's reputation in the market, enhancing the shareholders' engagement, avoiding costly strikes, and boosting the employees' productivity, higher level of employee welfare would be expected to mitigate stock crash risks". ${ }^{23}$

Furthermore, no salary is paid for 2 (two) years, it can mean that PT. Kertas Lecess is experiencing financial problems. This is according to Ellen Toback's prediction which explains that : ${ }^{4}$ " Research on bankruptcy prediction has largely focused on traditional data such as financial ratios, stock data or macroeconomic data ".Ollof Wadel also said that " which makes the bankruptcy setting excellent for studies of not only risk factors, but also economic". 25

\footnotetext{
20 Daphne Chena,, JakeZhao, The impact of personal bankruptcy onlabor supply decisions, P .41

${ }^{21}$ Yang, G. (2018). Welfare Under Friction and Uncertainty: General Equilibrium Evaluation of Temporary Employment in the U.S. Research in Economics.doi:10.1016/j.rie.2018.07.005

${ }^{22}$ Lin, C., Schmid, T., \& Xuan, Y. (2014). Employee Representation and Financial Leverage. SSRN Electronic Journal. doi:10.2139/ssrn.2544223

${ }^{23}$ Ben-Nasr, H., \& Ghouma, H. (2018). Employee welfare and stock price crash risk. Journal of Corporate Finance, 48, 700-725.doi:10.1016/j.jcorpfin.2017.12.007

${ }^{24}$ Ellen Tobback, Tony Bellotti, Julie Moeyersoms, Marija Stankova, David Martens, 2017, Bankruptcy prediction for SMEs using relational data, Decision Support Systems, HIm.2 diunduh dari : http://10.1016/i.dss.2017.07.004

${ }^{25}$ Olof Wadell, Anna Bengtson and Susanne Åberg, From dusk till dawn: Attracting suppliers for resource mobilization during bankruptcy, Journal of Purchasing and Supply Management,HIm.3, diunduh dari ,https://doi.org/10.1016/j.pursup.2019.03.001
} 
Then, according to Sutan Remy Sjahdeini, there are two ways provided by UUKPKPU so that debtors avoid the threat of their assets being liquidated when the debtor has been or will be in an insolvency situation. The first way is by submitting a Debt Delay Liability or better known as PKPU. Whereas the second way is to make peace. ${ }^{26}$

Meanwhile, the cancellation of homologation of peace began when PKPU No. peace happened. 05/PKPU/2014/ PN.Niaga.Sby on 18 May 2015, between the defendant Kertas Leces and the creditors was legal.

The court also ordered the parties, including the respondent, to carry out the contents of the peace agreement. The decision began with a vote by 14 creditors out of 22 creditors consisting of 10 creditors representing $80.7 \%$ of all concurrent creditor bills and 4 separatist creditors approved the PKPU peace plan submitted by PT. Kertas Lecess on May 4, 2015.

If in bankruptcy the debtor is no longer able to pay his debts. then in the PKPU the debtor is still able and able to pay its debts in full, only it takes extra time to improve the economic situation. The advantage for the debtor over this PKPU institution is that in a sufficient period of time it can fix the difficulties and finally be able to pay its debts and for creditors there is a high probability that the debtor can pay his debts.

Meanwhile, if declared bankrupt, all assets will be auctioned off and creditors may not necessarily get full payment. The consequences of PKPU are:27

a. The debtor cannot run the management actions or facilitate the rights to any part of his property, if the debtor violates the management has the right to do everything to ensure that the debtor's assets are not harmed because of the debtor's actions.

b. The debtor cannot be forced to pay his debts and all execution actions that have been initiated to get the repayment of the debt must be deferred.

c. Debtors have the right to pay their debts to all creditors together according to their respective receivable contributions.

d. All the encumbrances installed have ended.

In essence PKPU's aim is for peace. The peace function in the PKPU process is very important, even as the main goal for the debtor, where the debtor as the person who knows the company best, how the company is going forward, both potential and difficulty paying its debts from the possibilities can still rise again from debt bondage to all its creditors. Therefore these peace measures are to develop a new strategy for the debtor to be very important.

However, due to the difficulty of repayment of debts that may be due soon which temporarily cannot be resolved, the debtor is forced to make a peace concept, which this concept will later be offered to creditors, thus the debtor can still later, of course if This peace was agreed by the creditors to continue the debtor's company. In other words, the ultimate goal of PKPU is to achieve peace between the debtor and all creditors of the peace plan proposed/offered by the debtor.

PT. Kertas Lecess in its peace proposal agreed to restructure its debts worth Rp. 2.12 trillion of the total bills originating from 431 creditors.

\footnotetext{
${ }^{26}$ Katrin Martha, Akibat Hukum Kepailitan berdasarkan Putusan Pengadilan Niaga terhadap Eksekusi atas Harta Kekayaan Debitor Pailit di Pengadilan Negeri, Disiplin, Vol 3, 2016, HIm.2

${ }^{27}$ Richard Burton Simaputang, Aspek Hukum Dalam Bisnis, Rineka Cipta, 2003, HIm. 162
} 
The value consists of 747.86 billion held by preferred creditors with a grace period of payment for 5 years and a time period of 45 years. Meanwhile, as many as 1.5 trillion belonged to separatist creditors and 222.73 billion belonged to concurrent creditors.

The Commercial Court Judge Panel at the Surabaya Court granted all requests submitted by state-owned employees of PT. Kertas Lecess (Persero) in Probolinggo. The verdict of the panel of judges made around 1,900 employees of PT. Kertas Lecess Probolingggo breathe freely. ${ }^{28}$

The reading of this decision was attended by the legal team of PT. Kertas Lecess namely Eko Novriansyah Putra, Sahat Poltak Siallagan, Alfons Manuel Napitupulu, Indra Bayu, Vargan Deriana Ntawisastra, Straussy Tauhiddinia Qoyumi and Rifky Hidayat.

The request for a cancellation of peace (homologation) was made because the peace agreement through the postponement of the debt payment obligations (PKPU) in accordance with Law No. 37 of 2004 had not been realized.

If the peace plan is not reached or the Court rejects the peace plan, the Court must declare the Debtor in Bankruptcy. The court can reject the peace plan because:

1. Debtor property, including objects for which the right to hold property is exercised, is far greater than the amount agreed in peace

2. The implementation of peace is not sufficiently guaranteed.

3. The peace is achieved because of fraud, or agreement with one or more creditors, or because the use of other efforts that are not honest and regardless of whether the debtor or other parties work together to achieve this.

4. Service fees and costs incurred by experts and administrators have not been paid or are not guaranteed for payment.

If the bankrupt debtor does not offer a peace plan, the peace plan is not accepted or the ratification of the peace is rejected based on a decision that has obtained permanent legal force, then by law the assets of bankruptcy will be in a state of insolvency. ${ }^{29}$

With the decision of PT. Kertas Lecess as a bankrupt company, the Panel of Judges requested that the employees of PT. Kertas Lecess got his rights in the form of salary and severance payment. This is based on article 95 paragraph (4) of Law Number 13 Year 2003 concerning Labor (hereinafter referred to as "UUK") which regulates labor privileges in the event of bankruptcy as follows:

"In the event that a company is declared bankrupt or is liquidated based on the prevailing laws and regulations, the wages and other rights of workers/laborers are debts that are paid first"

Furthermore, in article 165 UUK it says that:

"The employer can terminate the employment relationship with the worker/laborer because the company is bankrupt with the provisions that the worker/laborer has the right to severance pay in the amount of 1 (one) time Article 156 paragraph (2), reward for work tenure, in the amount of 1 (one) time provisions of Article 156 paragraph (3) and reimbursement of rights in accordance with article 156 paragraph (4) ".

${ }^{28}$ http://bumn.go.id/ppa/berita/1-Majelis-Hakim-Putuskan-PT-Kertas-Leces-Probolinggo-Pailit

${ }_{29}^{2}$ Selika Afrita, Akibat Hukum Kepailitan berdasarkan Putusan Pengadilan Niaga terhadap Eksekusi atas Harta Kekayaan Debitor Pailit di Pengadilan Negeri, Disiplin, Vol 3, 2016, HIm. 76 


\section{Employees Legal protection to get salary and severance payment}

In its decision, Chief Judge Harijanto conveyed several considerations. Among them, PT. Kertas Lecess was found guilty of negligence for the non-payment of the salaries of PT. Kertas Lecess employees. Thus, the panel of judges decided to grant Haris's request along with 14 people through his legal team. The verdict is a legal protection for employees to get salary and severance payment that has not been paid by PT. Kertas Lecess.

"Based on the above considerations, the Panel of Judges of the Surabaya District Court, decided to grant the request for a cancellation of peace (Homologation) and stated that PT. Kertas Lecess was proven guilty of negligence for the non-payment of the salaries of PT. Kertas Lecess employees, "explained judge Harijanto.

Caesar E. Tamayo said that: 30 " Our quantitative analysis shows that this feature of bankruptcy law can have important consequences for industry dynamics and aggregate outcomes"

Therefore, according to this opinion, it could mean that the panel of judges understood the importance of the position of the workers who had tried to save the financial problems of PT. Kertas Lecess. But the company's negligence is not the fault of the workers, and is a mistake in the management of the company's organization from all aspects. Thus the legal protection of workers has fulfilled a sense of justice when the Panel of Judges decided that there was negligence at PT. Kertas Lecess so the Judge ordered PT. Kertas Lecess to pay salaries and severance pay to its workers.

The legal counsel of PT. Kertas Lecess, Eko Novriansyah, after the trial was very appreciative of the judge's decision today. Because the judge decided with the principle of justice.

Please note, around 1900 employees of PT. Kertas Lecess Probolinggo paper sued the Directors of PT. Kertas Lecess to cancel the peace on the grounds of normative rights of employees, which on average amounted to nearly Rp 200 million until the fourth year, has not been paid. PT. Kertas Lecess, which is a BUMN, certainly has power (which governs) and has economic power.

Legal protection according to Philip, is always related to power, there are two powers that are always a concern namely government power and economic power. In relation to government power, the issue of legal protection for the people (governed), against the government (governing). In relation to economic power, the problem of legal protection is protection for the weak (economy) of the elbow (economy), for example protection for workers against employers.

Therefore it is appropriate if the employee sues the BUMN through the Commercial Court because it has violated an agreement that says two years employee rights must be paid. This is in line with the thinking of Blanton, R. G., Blanton, S. L., \& Peksen, D. (2015): )." ... financial crises affect collective labor rights". 31

30 Tamayo, C.E. 2017, Bankruptcy choice with endogenous financial constraints. Review of Economic Dynamics, HIm.1, http://dx.doi.org/10.1016/j.red.2017.06.004

${ }^{31}$ Blanton, R. G., Blanton, S. L., \& Peksen, D. (2015). Financial crises and labor: does tight money loosen labor rights?. World Development, 76, 1-12. 
The efforts of the employees to sue the BUMN certainly incurred the cost of registering a lawsuit. So it is very possible if the whole trial process can prove the negligence of PT. Kertas Lecess, all employee rights that have not been paid will be granted by the judge. Through the judge's decision, the obligation for PT. Kertas Lecess against employees must be comparable. This is consistent with Andrew Ellul's statement that " "liabilities to employees are typically of comparable magnitude". ${ }^{32}$ But in fact, the salary that should be paid according to the work contract is impossible to pay off. This is contrary to the opinion of Bryson, A., Buraimo, B., \& Simmons, R. (2011) states that, "Most workers are on salaried contracts. " 33

As a result of the lack of clarity on the payment and the weak financial management of the company, PT. Kertas Lecess submitted the case to the Surabaya District Court. With case number numbered: 1/Pdt.Sus-Cancellation of Peace/2018/PN Niaga Sby Jo. number: 5/PKPU/2014/PN Niaga Sby. This is consistent with the opinion of Ranasinghe, A., \& Restuccia, D. (2018) that "Weaker financial development and rule of law have substantial negative effects on aggregate output ".

Pursuant to Article 21 of Law Number 37 of 2004, bankruptcy covers all debtors' wealth at the time the bankruptcy statement is decided along with everything obtained during the bankruptcy. With the bankruptcy decision, the debtor by law loses his right to control and manage his wealth which is included in the bankruptcy assets from the date the bankruptcy decision was pronounced. ${ }^{34}$

Hundreds of paperworkers at PT. Kertas Lecess, Probolinggo, asked the supervising judge from the Surabaya Commercial Court, to immediately decide on severance pay for employees affected by layoffs. ${ }^{35}$

"The arrival of the employees to this court office to request immediate to pay the severance payment becaused layoffs," said Indra Bayu, attorney for PT. Kertas Lecess workers in front of the Surabaya Commercial Court office.

Indra explained, PT. Kertas Lecess is a state-owned enterprise (BUMN), which went bankrupt in September 2019. There were around 1800 workers who had to receive termination of employment. The value of severance payment for workers affected by layoffs is around Rp. 300 billion. The consequence of bankruptcy is that the debtor by law loses his right to control and manage his wealth which is included in bankruptcy assets, from the date the statement of bankruptcy is pronounced.

This is also confirmed in Paragraph 9 of the General Explanation of PKPU Law which states:

Decision of bankruptcy statement changes a person's legal status to be incompetent to carry out legal actions, control, and manage their assets since the verdict of a bankrupt statement is made.

In principle, bankruptcy covers all debtors' wealth when the statement of bankruptcy is carried out along with all assets obtained during bankruptcy. With a bankrupt

\footnotetext{
${ }^{32}$ Andrew Ellul a , Marco Pagano, Corporate leverage and employees' rights in bankruptcy, hlm.1, sumber : www.elsevier.com/locate/jfec

${ }^{33}$ Bryson, A., Buraimo, B., \& Simmons, R. (2011). Do salaries improve worker performance?. Labour Economics, 18 (4), 424-433.

34 Kartini Mulyadi, Gunawan Widjaja, Pedoman Menangani Perkara Kepailitan, Raja Grafindo Persada, Jakarta, 2003, P.1

35 https://jatimnow.com/baca-14008-pabrik-kertas-leces-pailit-karyawan-demo-minta-pencairanpesangon
} 
statement, the bankrupt debtor by law loses the right to control and manage his wealth which is included in the bankruptcy, starting from the date of the bankruptcy.

Article 23 of the Bankruptcy Law stipulates that all bankruptcy debtor engagements made after the bankruptcy statement cannot be paid for from bankrupt assets unless the agreements bring profits to those assets. Therefore, lawsuits originating from the rights and liability of bankrupt debtor assets must be filed against or by the curator. Likewise, all lawsuits with the aim of fulfilling the agreement of bankruptcy assets during the bankruptcy, even if filed with the bankrupt debtors themselves, can only be filed with reports or matching them.

Richard Burton Simaputang, said ${ }^{36}$ that another very important legal consequence of the bankruptcy statement is that as stated in Article 41 of the Bankruptcy Law, namely that for the purposes of bankruptcy assets, cancellation of all legal actions of the debtor which has been declared bankrupt is detrimental to the interests of the creditor, which carried out before the bankruptcy statement is determined. Even this cancellation can only be done if it can be proven that at the time the legal action was carried out by the debtor and the party with whom the legal action was carried out knew or duly knew that the legal action would result in a loss for the creditor, except for legal actions committed by the debtor must be done based on the agreement and or due to the law, for example tax payment obligations. Even for grants made by the debtor can be asked for cancellation if the curator can prove that at the time the grant was made the debtor knows or deserves to know that the action will cause harm to creditors (Article 43 of the Bankruptcy Act).

Richard Burto Simatupang further said that: Another legal consequence is the right of retention regulated in Article 59, namely the creditor's right to hold debtors' belongings until a debt is paid does not lose the right to hold the goods by saying a bankrupt statement. If the curator intends to redeem these items, then the curator must repay the bankrupt debtor's debt first.

Hearing this news, the paper mill workers also asked the Bankrupt Supervisor Judge of the Surabaya Commercial Court to immediately decide severance payments to workers. This is in accordance with the objective of bankruptcy law that, the first objective, bankruptcy law secures and distributes the proceeds of the sale of Debtor property fairly to all of its creditors. The second objective, is to prevent insolvent Debtors from harming the interests of their Creditors. In other words, bankruptcy law not only provides protection to creditors from other fellow creditors but also provides protection to creditors from debtors. The third objective of bankruptcy law is to provide protection to Debtors in good faith from their Creditors. ${ }^{37}$

\section{CONCLUSION}

1. The rules that form the basis for severance payment for PT. Kertas Lecess that was laid off was Law Number 37 of 2004 concerning Bankruptcy and Delaying Obligations for Debt Payment Jo. Law Number 13 of 2003 concerning Labor. MK Decision No. 67/PUU-XI/2013. The laws and regulations have been implemented right in the case of PT. Kertas Lecess to declare that the company has been negligent so decided bankrupt.

\footnotetext{
${ }^{36}$ Richard Burton Simaputang, Aspek Hukum Dalam Bisnis, Rineka Cipta, 2003, P. 162

37 Immanuel Rahmani, Perlindungan Hukum Kepada Pembeli dalam Kepailitan Pengembangan (Developer) Rumah Susun, Jurnal Hukum Bisnis Commun Commune, Vol 1. Agustus 2018, P. 75
} 
2. There are around 1800 workers who must receive termination of employment (PHK). The value of severance payment for workers affected by layoffs is around Rp. 300 billion. Employees Legal protection of PT. Kertas Lecess is based on Decision Number 1/Pdt. Sus-Cancellation of Peace/2018/PN Niaga Sby Jo. Decision Number: 5/PKPU/2014/PN Niaga Sby. However, even though the court's ruling requires prioritizing severance payments, in reality severance payments cannot be paid in full because of the limited value of the auction results.

\section{REFERENCES}

\section{Books}

Bogdan, R. C. \& Biklen, S. K.,1982. Qualitative research for education: an introduction to the theory and methods. Boston: Allyn and Bacon, Inc.

Moleong, L. J, Metodologi Penelitian Kualitatif. Remaja Rosdakarya., Bandung, 1998.

M. Nazir, Metode Penelitian, Ghalia Indonesia, Jakarta, 2003.

Philipus M Hadjon, "Perlindungan Hukum Dalam Negara Hukum Pancasila", Armico, Bandung, 2003.

Richard Burton Simaputang, Aspek Hukum Dalam Bisnis, Rineka Cipta, 2003.

Ronny Hanitijo Soemitro, Metode Penelitian Hukum dan Jurimetri, Ghalia Indonesia, 1993.

Victor M. Situmorang, Hendri. Soekarso, Pengantar Hukum Kepailitan di Indonesia, Rineka Cipta, Jakarta, 1994.

\section{Journal}

Andrew Ellul a , Marco Pagano, Corporate leverage and employees' rights in bankruptcy, sumber : www.elsevier.com/locate/ifec.

Ben-Nasr, H., \& Ghouma, H. (2018). Employee welfare and stock price crash risk. Journal of Corporate Finance, 48, 700-725.doi:10.1016/j.jcorpfin.2017.12.007

Blanton, R. G., Blanton, S. L., \& Peksen, D. (2015). Financial crises and labor: does tight money loosen labor rights?. World Development, 76.

Boeri, T., Garibaldi, P., \& Moen, E. R. (2018). Financial constraints in search equilibrium: Mortensen Pissarides meet Holmstrom and Tirole. Labour Economics, 50, 144-155. doi:10.1016/j.labeco.2017.06.003

Bryson, A., Buraimo, B., \& Simmons, R. (2011). Do salaries improve worker performance?. Labour Economics, 18 (4).

Caggese, A., Cuñat, V., \& Metzger, D. (2018). Firing the Wrong Workers: Financing Constraints and Labor Misallocation. Journal of Financial Economics.doi:10.1016/j.jfineco.2017.10.008

Daphne Chena, JakeZhao, The impact of personal bankruptcy onlabor supply decisions, Sumber : www.elsevier.com/locate/red 
Ellen Tobback, Tony Bellotti, Julie Moeyersoms, Marija Stankova, David Martens, Bankruptcy prediction for SMEs using relational data, Decision Support Systems (2017), diunduh dari : http://10.1016/j.dss.2017.07.004

Espinosa, R., Desrieux, C., Ferracci, M. (2018). Labor market and access to justice. International Review of Law and Economics, 54, 1-16. doi:10.1016/j.irle.2017.09.008

Igor Klioutchnikova, Mariia Sigovaa, Nikita Beizerova Chaos Theory in Finance, 6th International Young Scientists Conference in HPC and Simulation, YSC 2017, 1-3 November 2017, Kotka, Finland, sumber : www.sciencedirect.com

Immanuel Rahmani, Perlindungan Hukum Kepada Pembeli dalam Kepailitan Pengembangan (Developer) Rumah Susun, Jurnal Hukum Bisnis Commun Commune, Vol1. Agustus 2018, diunduh dari : https://www.researchgate.net/publication/328937030 PERLINDUNGAN HUK UM_KEPADA_PEMBELI_DALAM_KEPAILITAN_PENGEMBANG_DEVELOPER_RU MAH SUSUN

Katrin Martha Ulina, etl al., Akibat Hukum Putusan Penolakan Pkpu Terhadap Debitor (Kajian Hukum Atas Putusan Pengadilan Niaga Jakarta Pusat Nomor: 28/Pkpu/2011/Pn.Niaga.Jkt.Pst.), Diponegoro Law Review, Volume 1, Nomor 4, Tahun 2012, diunduh dari https://ejournal3.undip.ac.id/index.php/dlr/article/view/476

Lin, C., Schmid, T., Xuan, Y. (2014). Employee Representation and Financial Leverage. SSRN Electronic Journal. doi:10.2139/ssrn.2544223

Olof Wadell, Anna Bengtson and Susanne Åberg, From dusk till dawn: Attracting suppliers for resource mobilization during bankruptcy, Journal of Purchasing and Supply Management, diunduh dari ,https://doi.org/10.1016/j.pursup.2019.03.001.

Ranasinghe, A., \& Restuccia, D. (2018). Financial frictions and the rule of law. Journal of Development Economics, 134.

Serlika Afrita, Akibat Hukum Kepailitan berdasarkan Putusan Pengadilan Niaga terhadap Eksekusi atas Harta Kekayaan Debitor Pailit di Pengadilan Negeri, Disiplin, Vol 3, 2016, diunduh dari http://stihpada.ac.id/system/App/Post/files/000/000/118/original/D121608. pdf.

Soeprapti, Kepailitan Debitur ditinjaudari kaca mata hukum, Ekuitas Vol.2 No.1 Maret 1998 yang diunduh dari https://www.researchgate.net/publication/313777282 KEPAILITAN DEBITUR DITINJAU DARI KACAMATA HUKUM

Tamayo, C.E. Bankruptcy choice with endogenous financial constraints. Review of Economic Dynamics (2017), http://dx.doi.org/10.1016/j.red.2017.06.004

Yang, G. (2018). Welfare Under Friction and Uncertainty: General Equilibrium Evaluation of Temporary Employment in the U.S. Research in Economics.doi:10.1016/j.rie.2018.07.005 


\section{Laws}

Undang-Undang Nomor 37 Tahun 2004 Tentang Kepailitan dan Penundaan Kewajiban Pembayaran Utang

Undang-Undang Nomor 13 Tahun 2003 Tentang Ketenagakerjaan

Putusan MK No. 67/PUU-XI/2013

Putusan Nomor 1/Pdt.Sus-Pembatalan Perdamaian/2018/PN Niaga Sby

Putusan Nomor: 5/PKPU/2014/PN Niaga Sby.

\section{Websites}

https://ekonomi.kompas.com/read/2018/11/06/054600026/pt-kerta-leces-pailitkurator-bereskan-aset

https://jatimnow.com/baca-14008-pabrik-kertas-leces-pailit-karyawan-demo-mintapencairan-pesangon

http://www.pubinfo.id/instansi-525-pt-kertas-leces-persero.html https://id.wikipedia.org/wiki/Kertas_Leces https://nasional.kontan.co.id/news/ppa-berhasil-jual-aset-kertas-leces-dalam-pailit http://www.djkn.kemenkeu.go.id/berita_media/baca/12885/Penyelesaian-AsetSelangkah-Lagi.html

http://bumn.go.id/ppa/berita/1-Majelis-Hakim-Putuskan-PT-Kertas-LecesProbolinggo-Pailit https://jatimnow.com/baca-14008-pabrik-kertas-leces-pailit-karyawan-demo-mintapencairan-pesangon 
